\title{
https://doi.org/10.46344/JBINO.2021.v10i02.06
}

\section{UDAR-VIPATAN IN MUDHAGARBHA}

Dr Mundhe Mangesh Gopinath ${ }^{1}$ \& Dr Mistry Awatar shingh Sohan shingh ${ }^{2}$

1.Professor\& H.O.D ,Dept of Prasutitantra Avum Streerog ,Dhanwantari Ayurved Medical college \&Hospital Udgir Dist-Latur 2.Professor\& H.O.D ,Dept of kaumarbhrityatantra, Dhanwantari Ayurved Medical college Udgir Dist-Latur

Email: drmangeshmundhe@gmail.com

\begin{abstract}
Maternal and Infant mortality is still a big problem in Modern scenario. Different complications during preconception, antenatal, intranatal and postnatal period are increasing day by day. Ayurveda has given prime importance to Antenatal and Intranatal care of women and her baby. In spite of good care sometimes labour has unpredictable outcomes, previously normal labour suddenly landed up into abnormal or obstructed labour. In present paper we are discussing regarding the udar vipatan in mudagarbha
\end{abstract}

Keyword: Garbini Parcharya, Ayurveda

No: of References: 24 


\section{INTRODUCTION}

According to Susruta, in a woman who has died during labour just like a killed goat, if quivering of abdomen still persists, the abdomen should immediately be opened and fetus extracted.Dalhana has explained that the procedure should be done in ninth month and in a woman who has died accidently all of sudden, in the same way goat throttled without much trouble, in such case immediately within two Ghatiesor one Muhurta. i.e., 48 minutes the fetus should be extracted by laparotomy or else fetus will die.

Vangasena also agrees with Dalhana.

$\neg$

Vagbhat have mentioned that during delivery of full term fetus if quivering of abdomen over Vastidwara of a dead woman still persists, the fetus should immediately be delivered by

laparotomy.Indu says that laparotomy should be performed over bladder region.Arundutta has explained that if the abdomen of dying woman during first stage of labour excessively quivers near the bladder region, then the expert physician should perform the laparotomy during interval period of quivering and extract the fetus.

\section{Explanation of Udar Vipatan}

1. Only nine month or full term fetus should be delivered by laparotomy, because premature fetus even if delivered may not survive.
2. quivering of abdomen is indicative of alive fetus.

3. During first stage of labour fetal head/presenting part remains high up or in false pelvis in majority of cases, it does not descend to pelvic cavity, quivering near bladder region also indicates this very fact.

4. Excessive movement indicates too much uterine contractions and relaxations; extraction of fetus during uterine contraction is very much difficult. Arundutta has advised extraction of fetus situated near urinary bladder, in first stage of labor.

Childbirth is a blessing to a women given from God. The passage of time caused unprecedented obstacle in the progress of Ayurveda, the oldest and most accurate science of life. The obstacle was relatively more marked in the field of Prasutitantra and Streeroga due to various social, ethical, moral and legal reasons. Concept of Mudhagarbha described in various Ayurvedic Samhitas is very unique and scientific. Mudhagarbha actually includes all the conditions of obstructed labour described in modern science along with its effective management. The literal meaning of the word Mudha is derived from dhatu "muh" i.e., to become stupefied, unconscious or swooned, to become bewildered or going in wrong direction and become lazy

5. Explanation given by Dalhana and Vangasena is more logical, because if the woman dies due to other causes 
such as toxemia of pregnancy, very prolonged labour or any other complications, the disorder have its impact on the fetus which may not survive even if delivered, however when woman dies an accidental death, the chances of survivality of fetus may increase.

6. Normally fetus dies immediately following death of the mother, hence utility of this description is doubtful, however in rare instances one may deliver a living fetus by laparotomy even after a bit prolong time of woman's death. Munro Kerr in his operative obstetrics has reported that in one instance an operation performed at least fifteen minutes after the death of the mother resulted in the delivery of a healthy baby

\section{REFERENCES}

Kaviraja Ambika Dutta Shastri, Susruta Samhita, Choukhamba Sanskrit sansthan, Varanasi, Reprint edition 2014 Nidansthan 8/4, Page No. 337.

Kaviraja Ambika Dutta Shastri, Susruta Samhita, Choukhamba Sanskrit sansthan, Varanasi, Reprint edition 2014 Nidansthan 8/3, Page No. 336.

\section{Pandit Hariharprasada Tripathi, Harita} Samhita, Choukhamba Sanskrit sansthana, Varanasi 2004, Tritiyasthan, 52/1-3.

Prof.Premvati Tiwari, Ayurvediya Prasuti tantraevam Streeroga, 1st part, Chapter no 8, Page no 490. .

Atridev Gupta, Astanga Sangraha, Choukhamba Orientalia, Varanasi, 1979, Sharirasthana 4/34.
Pandit Hariharprasada Tripathi, Harita Samhita, Choukhamba Sanskrit sansthana, Varanasi 2004, Tritiyasthan, 52/4-8.

Kaviraja Ambika Dutta Shastri, Susruta Samhita, Choukhamba Sanskrit sansthan, Varanasi, Reprint edition 2014 Nidansthan 8/5, Page No. 337.

Atridev Gupta, Astanga Sangraha, Choukhamba Orientalia, Varanasi, 1979, Sharirasthana 4/34.

Kaviraja Ambika Dutta Shastri, Susruta Samhita, Choukhamba Sanskrit sansthan, Varanasi, Reprint edition 2014 Nidansthan 8/7, Page No. 338.

Atridev Gupta, Astanga Sangraha, Choukhamba Orientalia, Varanasi, 1979, Sharirasthana 4/30.

Dr.Brahmananda Tripathi, Madhavanidanam, Chaukhamba surabharati prakasan, Varanasi 2005, chapter 64/3.

Kaviraja Ambika Dutta Shastri, Susruta Samhita, Choukhamba Sanskrit sansthan, Varanasi, Reprint edition 2014 Chikitsasthana 15/13, Page No. 93.

Kaviraja Ambika Dutta Shastri, Susruta Samhita, Choukhamba Sanskrit sansthan, Varanasi, Reprint edition 2014 Nidansthan 8/8, Page No. 339.

Kaviraja Ambika Dutta Shastri, Susruta Samhita, Choukhamba Sanskrit sansthan, Varanasi, Reprint edition 2014 Nidansthan 8/8, Page No. 339.

Kaviraja Ambika Dutta Shastri, Susruta Samhita, Choukhamba Sanskrit sansthan, Varanasi, Reprint edition 2014 Chikitsasthana 15/12, Page No. 93. Ibid; Chikitsasthana 15/10, Page No.93. 2 
Kaviraja Ambika Dutta Shastri, Susruta

Samhita, Choukhamba Sanskrit sansthan, Varanasi, Reprint edition 2014 Chikitsasthana 15/3, Page No. 91.

Kaviraja Ambika Dutta Shastri, Susruta Samhita, Choukhamba Sanskrit sansthan, Varanasi, Reprint edition 2014 Chikitsasthana 15/9, Page No. 92.

Kaviraja Ambika Dutta Shastri, Susruta Samhita, Choukhamba Sanskrit sansthan, Varanasi, Reprint edition 2014 Chikitsasthana 15/12, Page No. 93. Ibid; 15/20-28, Page No. 93

Kaviraja Ambika Dutta Shastri, Susruta Samhita, Choukhamba Sanskrit sansthan, Varanasi, Reprint edition 2014 Nidanasthana 15/9, Page No. 92

Prof.Premvati Tiwari, Ayurvediya Prasuti tantraevam Streeroga, 1st part, Chapter no 8, Page no 541

Dr.Brahmananda

Tripathi,

Madhavanidanam, Chaukhamba surabharati prakasan, Varanasi 2005 , chapter 64/3.

Kaviraja Ambika Dutta Shastri, Susruta Samhita, Choukhamba Sanskrit sansthan, Varanasi, Reprint edition 2014 Nidansthan 8/3, Page No. 337.

Atridev Gupta, Astanga Sangraha, Choukhamba Orientalia, Varanasi, 1979, Sharirasthana 4/29, Page No. 337.

Priyavrat Sharma, Susruta Samhita with Dalhana commentary, volume 2, Chaukhamba Viswabharati, Varanasi 2013, Nidansthan $8 / 3$ 